\title{
Isolation and Identification of Flavonoid Derivative Compounds from n-Butanol Fraction of Red Pakoba (Syzygium sp.)
}

\author{
Gabriel Kahiking*, Rymond J. Rumampuk, Emma J. Pongoh
}

a Kimia, Universitas Negeri Manado, Tondano, 95619, Indonesia

\section{INFO ARTIKEL}

Diterima 23 Mei 2020

Disetujui 26 Oktober 2020

\section{Key word:}

Isolation

Identification

Red Pakoba (Syzygium sp.)

Flavonoid derivative compounds

Kata kunci:

Isolasi

Identifikasi

Pakoba Merah (Syzygium sp.)

Senyawa Glikosida

*e-mail:

gabriel.kahiking@yahoo.co.id

\begin{abstract}
A B S T R A C T
The red pakoba (Syzygium sp.) is a plant originating from North Sulawesi that is often used by local people as a basic ingredient of medicine. This research was conducted to isolate and identify flavonoid derivative compounds contained in the nbutanol fraction of red pakoba fruits (Syzygium sp.). The isolation process was carried out using the maceration method, for the separation and purification of compounds using Thin Layer Chromatography (TLC) and Gravity Column Chromatography and obtained $F_{2.4}$ sub-fraction isolates with a sample weight of 4.5 $m g$. Identification of compound using the Proton Nuclear Magnetic Resonance ( $\mathrm{H}$ NMR) and Carbon Nuclear Magnetic Resonance(C-NMR) techniques. The results of identification of isolate F2.4 sub-fraction as flavonoid derivative compounds with the proposed name 3-O-methyl-butyrate-6,7,3',4' tetrahydroxy-5-methoxy-8-methyl flavan with molecular formula $\mathrm{C}_{22} \mathrm{H}_{25} \mathrm{O}_{8}$.
\end{abstract}

\section{A B STR A K}

Pakoba merah (Syzygium sp.) merupakan tumbuhan yang berasal dari Sulawesi Utara yang sering digunakan oleh masyarakat setempat sebagai bahan dasar obat. Penelitian ini dilakukan untuk mengisolasi dan mengidentifikasi senyawa turunan flavonoid yang terkandung dalam fraksi n-butanol buah pakoba merah (Syzygium sp.) Proses isolasi dilakukan menggunakan metode maserasi, untuk pemisahan dan pemurnian senyawa menggunakan metode Kromatografi Lapis Tipis (KLT) dan Kromatografi Kolom Gravitasi dan diperoleh isolat sub-fraksi $F_{2.4}$ dengan berat sampel 4,5 mg. Identifikasi senyawa menggunakan teknik Resonansi Magnetik Inti Proton (H-RMI) dan Resonansi Magnetik Inti Karbon (C-RMI). Hasil identifikasi isolat sub-fraksi $\mathrm{F}_{2.4}$ sebagai senyawa turunan flavonoid dengan usulan nama 3-O-metil-butirat-6,7,3', $4^{\prime}$ tetrahidroksi-5-metoksi-8-metil flavan dengan rumus molekul $\mathrm{C}_{22} \mathrm{H}_{25} \mathrm{O}_{8}$.

\section{Introduction}

Red Pakoba an endemic plant from North Sulawesi Province, this plant belongs to the genus Syzygium which has similar properties to other plants that have similar Latin names such as Syzygium aromaticum, Syzygium Cumini (L), and Syzygium luzonense. The fruit of this plant is used by the local people as a basic ingredient for making drugs because it has pharmacological functions such as antioxidants and antidiabetic [1-10].

In general, the genus Syzygium contains secondary metabolites in the form of flavonoids, alkaloids, tannins and terpenoids which are used in the world of medicine, mostly, for anti-inflammatory, pain relief and anti-fungal $[\underline{11}, \underline{12}]$.

Some active compounds such as myricetin (3-O-(4"-O-acetyl-2"-O-gallolyl)- $\alpha$-Lrhamnopyranoside) and mearnsetin (3-O-(4 "-Oacetyl)- $\alpha$-L-rhamnopyranoside) which has been isolated from the leaves of Syzygium cumini L. [13]. Flavonoid compounds are compounds that are commonly found in plants, no exception to Red Pakoba (Syzygium sp.)[14].

To get the compound contained in the red Pakoba fruit (Syzygium sp.), the isolation and identification process was carried out. The 
isolation stage uses the extraction method, whereas for identification using the Proton Nuclear Magnetic Resonance (H-NMR) and Carbon Nuclear Magnetic Resonance (C-NMR) spectrometry.

\section{Material and Method}

Plant sample the Red Pakoba fruit (Syzygium sp.) obtained from Laikit Village, located in North Minahasa Regency, size 230400 mesh silica gel, silica gel $60 \mathrm{GF}_{254}$, butanol, ethyl acetate, dichloromethane, methanol, distilled water, Thin Layer Chromatography (TLC), $10 \% \mathrm{H}_{2} \mathrm{SO}_{4}$ solution in ethanol as stain emerger, and other materials such as Whatman 42 filter paper, aluminium foil, and label paper.

The equipment used was Beaker glass, measuring cup, Erlenmeyer, funnel, pipette, chamber, chromatographic column, vial bottle. A set of re-distillation apparatus, a set of rotary vaporizers (Rotavapor Buchi), Buchner funnel, analytical scale, oven, hotplate, spatula, tweezers, scissors, ruler and pencil. Compound analysis were conducted using JEOL $500 \mathrm{MHz}$ Proton Nuclear Magnetic Resonance (H-NMR) and JEOL $125 \mathrm{MHz}$ Carbon Nuclear Magnetic Resonance (C-NMR) spectroscopy.

\section{Extraction stage}

Red pakoba fruit (Syzygium sp.) was mashed using a blender, then macerated $7 \times 24 \mathrm{~h}$ with ethanol solvent whose level is $70 \%$, allowed to stand for 24 hours until the filtrate is obtained. The filtrate obtained was then evaporated.

\section{Separation and Purification of Compounds}

A thick ethanol extract weighed $50 \mathrm{~g}$ was added with silica gel weighed $50 \mathrm{~g}$ and crushed to obtain powder. The powder was then eluted with $1 \mathrm{~L}$ of butanol solvent using a Buchner funnel and vacuum until a filtrate was obtained and evaporated.

The butanol extract obtained was dissolved in a $10 \mathrm{~mL}$ methanol solvent and 300 $\mathrm{mL}$ petroleum ether then filtered using filter paper yielded petroleum ether filtrate and butanol crude. The butanol krud was chromatographed with columns in a gradient with several volume ratio of ethyl acetate: Methanol. The results of TLC were each sprayed with $10 \% \mathrm{H}_{2} \mathrm{SO}_{4}$ as a stain emerger. Combination of solvents that produce a good separation pattern on TLC is used as an eluent in gravity column chromatography. The results obtained from column chromatography (eluate) are collected in vials and analysed by TLC. The TLC results obtained (in a vial bottle) are selected which have the same Rf number then combined. Eluate which still has two or more stains on TLC, then will have to be going under column chromatography again. This stage is continued until a pure compound is obtained. The pure compound was then further analyzed using the Proton Nuclear Magnetic Resonance (H-NMR) and Carbon Nuclear Magnetic Resonance (C-NMR) spectrometry.

\section{Result and Discussion}

Compound Extraction

$2.92 \mathrm{~kg}$ of red pakoba was macerated using $70 \%$ ethanol for $7 \times 24$ hours and produced 10.927 litre of filtrate. The filtrate was then evaporated then yield $258.61 \mathrm{~g}$ thick ethanol extract of red pakoba (Syzygium sp).

\section{Separation and Purification of Compounds}

The first step is weighing $50 \mathrm{~g}$ of red pakoba ethanol extract and $50 \mathrm{~g}$ of silica gel and crushed evenly until it becomes powder. The powder obtained was then eluted using butanol, yielding filtrate. The butanol filtrate was then evaporated and yielding 15,32 $\mathrm{g}$ of butanol extract of red pakoba in the form of solids with a hard texture. Red pakoba butanol extract of $15.3191 \mathrm{~g}$ was put in a beaker glass and dissolved in $10 \mathrm{~mL}$ of methanol, added with excess Petroleum Ether. The addition of petroleum ether here aims to clean the butanol extract which is coated by a layer of fat so that it has a hard texture. The filtered extract produced filtrate and residue in the form of soft solids, because the fat layer has been successfully removed. The residue obtained was evaporated in a fume hood and a net residual weight of $5.72 \mathrm{~g}$ was obtained.

The second step taken was the gradient chromatography column. $5.72 \mathrm{~g}$ of butanol Crude was crushed with silica gel until it turned into powder. Soaking silica gel as much as $73.9 \mathrm{~g}$ for 24 hours to be used as a stationary 
phase. Column process were carried out by ratio of ethyl acetate: methanol eluents which eluted the solvent 7 times in a row. The results of the column are contained in vials of $10 \mathrm{~mL}$ each, resulted 37 vials. The eluate obtained was analysed by TLC using volume ratio of the ethyl acetate: methanol (7: 3) eluent. Based on the stain pattern on TLC eluate which have the same stains combined, 7 eluate groups were obtained. The results of TLC on 7 groups of eluate showed that eluate 2 and 3 had the same Rf value, so were eluate 4 and 5, therefore eluate 2 and 3 were combined, and also eluate 4 and 5 were combined so that the number of fractions obtained was 5 fractions (F .1 - F.5). F.2 fraction was chosen for the rechromatography step because it has a good spot pattern which has 1 stain. F.2 fraction of $0.566 \mathrm{~g}$ was dissolved in dichloromethane: methanol (9: 1) sufficiently, column chromatography was performed using the same eluent. The stationary phase used is 74,01 $\mathrm{g}$ of silica gel which has been immersed in eluent for 24 hours. Eluate were collected in vials of $5 \mathrm{~mL}$ each with 185 vials obtained. The 100-150 vial bottle was re-tested for TLC because it had a stain pattern with similar Rf spacing to find out which fraction had good separation in the presence of one stain, which indicated that the sample was relatively pure and already contained one compound.

The 100-109 vial bottle was selected and then combined and evaporated because it already has a stain separation pattern which indicates that the sample is relatively pure and contains at least one compound.

\section{Analysis of Isolate Spectrum}

F2.4 sub-fraction was elucidated using the Proton Nuclear Magnetic Resonance (H-NMR) and Carbon Nuclear Magnetic Resonance (CNMR) spectrometry. Sample F2.4 weighing 4.5 $\mathrm{mg}$ was dissolved in chloroform-D $\left(\mathrm{CDCl}_{3}\right)$ solvent. The spectrum was recorded on a 500 MHz JEOL spectrometer for Protons and 125 $\mathrm{MHz}$ for Carbon.

Based on spectrum data fraction 2.4 has a framework of flavonoid compound with the chemical shift H-2 (4.56, d, J = 6.5 Hz), H-3 (4.1, $\mathrm{m}), \mathrm{H}-4(2.94, \mathrm{~d}, \mathrm{~J}=4 \mathrm{~Hz} \& 2.93, \mathrm{~d}, \mathrm{~J}=4$ $\mathrm{Hz})[15]$. The glycosidic bond is shown by the chemical shift of oxygenated carbon at position C-3 ( $\delta C$ 69.0) which attached to a methylbutyric acid and was supported by the chemical shift $\delta \mathrm{H} 2.04$ (H-2 "'), 1.58 (H-3'"), 1.29 (H-4 "') and 0.87 (H-5"') which is the chemical shifting regions for methylene, methylene and methyl compounds [16]. The position of methyl butyric acid is bound to C-3, also indicated by the presence of anomeric proton signal $\mathrm{H}-3$ at $\delta \mathrm{H} 4.1(\mathrm{~m})$. Isolate $\mathrm{F} 2.4$ on ring A has proton chemical shifts $\delta \mathrm{H} 7.0$ and 6.49 on $\mathrm{H}-6$ and $\mathrm{H}-8$ because it attached to hydroxy $(\mathrm{OH})$ and methyl $\left(\mathrm{CH}_{3}\right)$ groups respectively, supported by the presence of NMR $-{ }^{13} \mathrm{C}$ carbon data on chemical shifts $\delta C 128.1,127.3,125.6$. Ring A also has a methoxy group $\delta \mathrm{H} 3.75$ $\left(\mathrm{OCH}_{3}\right)$ on carbon $\mathrm{C}-5$ supported by NMR-13 $\mathrm{C}$ carbon data on the chemical shift $\delta C 52.6$ [17]]. Data tabulation is shown in table 1.

Table 1. Spectrum tabulation H-NMR \& CNMR

\begin{tabular}{|c|c|c|}
\hline \multirow{2}{*}{ Position } & \multicolumn{2}{|l|}{ Fraction 2.4} \\
\hline & $\delta \mathrm{H}$ & $\delta \mathrm{C}$ \\
\hline 2 & $4.56(\mathrm{~d}, \mathrm{~J}=6.5 \mathrm{~Hz})$ & 82.7 \\
\hline 3 & $4.1(\mathrm{~m})$ & 69.0 \\
\hline \multirow[t]{2}{*}{4} & $2.94(\mathrm{~d}, \mathrm{~J}=4 \mathrm{~Hz})$ & 29.8 \\
\hline & $2.93(\mathrm{~d}, \mathrm{~J}=4 \mathrm{~Hz})$ & \\
\hline 5 & - & 145.9 \\
\hline 6 & - & 128.1 \\
\hline 7 & - & 127.3 \\
\hline 8 & - & 125.6 \\
\hline 9 & - & 148.6 \\
\hline 10 & - & 102.7 \\
\hline $1^{\prime}$ & - & 131.5 \\
\hline $2^{\prime}$ & $6.56(\mathrm{~m})$ & 115.2 \\
\hline $3^{\prime}$ & - & 142.4 \\
\hline $4^{\prime}$ & - & 142.4 \\
\hline $5^{\prime}$ & $6.49(\mathrm{~m})$ & 116.1 \\
\hline $6^{\prime}$ & $7.0(\mathrm{~m})$ & 121.0 \\
\hline 5-OMe & $3.75(\mathrm{~s})$ & 52.6 \\
\hline \multirow{2}{*}{ Position } & \multicolumn{2}{|c|}{ Methyl-butyrate } \\
\hline & $\delta \mathrm{H}$ & $\delta C$ \\
\hline $1^{\prime \prime}$ & - & 173.1 \\
\hline $2 "$ & $2.04(\mathrm{~m})$ & 44.4 \\
\hline $3 "$ & $1.58(\mathrm{~m})$ & 25.8 \\
\hline $4 "$ & $1.29(\mathrm{t})$ & 22.6 \\
\hline $5^{\prime \prime}$ & $0.87(\mathrm{~s})$ & 22.6 \\
\hline
\end{tabular}


The proposed structure for isolate F2.4 is a flavonoid derivative compound which has a molecular formula $\left(\mathrm{C}_{22} \mathrm{H}_{25} \mathrm{O}_{8}\right)$ with a flavonoid which consist of flavan type framework and the proposed structure name is 3-O-methylbutyrate-6,7,3 ', 4'-tetrahydroxy-5 -methoxy-8methyl flavan (Picture 1).

Picture 1. 3-O-methyl-butyrate-6,7,3 ', 4'tetrahydroxy-5 -methoxy-8-methyl flavan

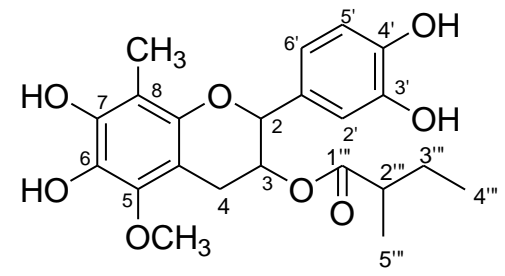

\section{Conclusion}

Flavonoid derivatives compound have been isolated and identified from F2.4 isolate sample of n-butanol fraction of red pakoba fruit (Syzygium $\mathrm{sp}$ ) with the proposed structure and name of compound 3-O-methylbutyrate-6,7,3',4'-tetrahydroxy-5-methoxy-8methyl flavan by molecular formula $\left(\mathrm{C}_{22} \mathrm{H}_{25} \mathrm{O}_{8}\right)$.

\section{References}

1. Wael, S.; Nuringtyas, T.R.; Wijayanti, N.; Astuti, P. Secondary Metabolites Production in Clove (Syzygium aromaticum): Chemical Compounds. Journal of Biological Sciences 2018, 18, 399406.

2. Kumar, A.; Ilavarasan, R.; Jayach, T.; Deecaraman, M.; Aravindan, P.; Padmanabhan, N.; Krishan, M.R.V. Antidiabetic activity of Syzygium cumini and its isolated compound against streptozotocin-induced diabetic rats. Journal of Medicinal Plants Research 2013, 2, 246-249.

3. Zhang, L.L.; Lin, Y.M. Antioxidant tannins from Syzygium cumini fruit. African Journal of Biotechnology 2009, 8.

4. Benherlal, P.S.; Arumughan, C. Chemical composition and in vitro antioxidant studies on Syzygium cumini fruit. Journal of the Science of Food and Agriculture 2007, 87, 2560-2569.

5. Sari, P.; Wijaya, C.H.; Sajuthi, D.; Supratman, U. Colour properties, stability, and free radical scavenging activity of jambolan (Syzygium cumini) fruit anthocyanins in a beverage model system: Natural and copigmented anthocyanins. Food Chemistry 2012, 132, 1908-1914.

6. Nahar, L.; Ripa, F.A.; Zulfiker, A.H.M.; Rokonuzzaman, M.D.; Haque, M.; Islam, K.M.S. Comparative study of antidiabetic effect of Abroma augusta and Syzygium cumini on alloxan induced diabetic rat. Agriculture and Biology Journal of North America 2010, 1, 1268-1272.

7. Alam, M.R.; Rahman, A.B.; Moniruzzaman, M.; Kadir, M.F.; Haque, M.A.; Alvi, M.R.-U.-H.; Ratan, M.D. Evaluation of antidiabetic phytochemicals in Syzygium cumini (L.) Skeels (Family: Myrtaceae). Journal of applied pharmaceutical science 2012, 2, 94.

8. Schoenfelder, T.; Warmlin, C.Z.; Manfredini, M.S.; Pavei, L.L.; Réus, J.V.; Tristão, T.C.; Fernandes, M.S.; CostaCampos, L. Hypoglycemic and hypolipidemic effect of leaves from Syzygium cumini (L.) Skeels, Myrtaceae. in diabetic rats. Revista Brasileira de farmacognosia 2010, 20, 222-227.

9. Singh, J.P.; Kaur, A.; Singh, N.; Nim, L.; Shevkani, K.; Kaur, H.; Arora, D.S. In vitro antioxidant and antimicrobial properties of jambolan (Syzygium cumini) fruit polyphenols. LWT-Food Science and Technology 2016, 65, 1025-1030.

10. Afify, A.E.-M.M.; Fayed, S.A.; Shalaby, E.A.; El-Shemy, H.A. Syzygium cumini (pomposia) active principles exhibit potent anticancer and antioxidant activities. African Journal of Pharmacy and Pharmacology 2011, 5, 948-956.

11. Kumajas, J.; Howan, D.H.O. Studi Kandungan Kimia Ekstrak Buah Pakoba Merah (Syzygium sp). Fullerene Journal of Chemistry 2018, 3, 58-62.

12. Walean, M.; Melpin, R.; Rondonuwu, M.; Pinontoan, K.F.; Maliangkay, H.P.; Astriani, M. Phytochemical screening and biological activities of pakoba (Syzygium luzonense) stem bark ethanol extract. Biodiversitas Journal of Biological Diversity 2020, 21.

13. Sikder, M.A.A.; Kaisar, M.A.; Rahman, M.S.; Hasan, C.M.; Al-Rehaily, A.J.; 
Rashid, M.A. Secondary metabolites from seed extracts of Syzygium cumini (L.). J Phys Sci 2012, 23, 83-87.

14. Sharma, M.; Panthari, P.; Pushpangadan, P.; Varma, A.; Kharkwal, H. Phytochemical Analysis of Glycosides from Leaves of Trigonella foenum graecum. International Journal of Pharmaceutical Sciences Review and Research 2014, 29, 146-152.

15. Achmad, S.A.; Murniana, M.; Udjiana, S.S.; Hakim, E.H.; Makmur, L.; Aimi, N. Three Flavan-3-ols from Artocarpus reticulates. Journal of Mathematical and Fundamental Sciences 1998, 30, 1-7.

16. Jenie, U.A.; Kardono, L.B.; Rumampuk, M.H.R.J.; Darmawan, A. Teknik Modern Spektroskopi NMR: Teori dan Aplikasi dalam Elusidasi Struktur Molekul Organik. 2014.

17. Harneti, D.; Iryanto, Y.; Sabarudin, L.; Nurlelasari, N.; Mayanti, T.; Safari, A.; Julaeha, E. Senyawa Katekin yang Bersifat Toksik dari Kulit Batang Tumbuhan Surian (Toona Sinensis). Bionatura 2013, 15, 218461.

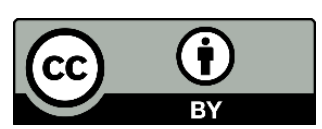

(C) 2020 by the authors. Licensee Fullerene Journal Of Chem. This article is an open access article distributed under the terms and conditions of the Creative Commons Attribution (CC BY) license

(http://creativecommons.org/licenses/by/4.0/). 